\title{
'LIKE TIDDLYWINKS FOR GROWN-UPS': COMMUNICATIVE ARTISTRY IN A 'WESTIE' COMEDY PERFORMANCE
}

\author{
Mike Lloyd
}

\begin{abstract}
Comedians develop and hone a persona that reflects their particular type of humour, thus greatly aiding in the economy that so typifies comedy performances. This paper considers the case of the well-known New Zealand comedian Ewen Gilmour, whose persona is a 'Westie' - someone from the working class area of West Auckland. This persona has equivalents in most countries, its central characteristics being hard-drinking, ready-swearing, stereotypical working class behaviour, which is also strongly gender typical. The paper focuses on one of Gilmour's short standup comedy performances filmed in front of a live audience and then screened on public television. The performance features a potential disjuncture: the Westie comedian narrates activities he engages in with a 'mate' that could be interpreted as 'homoerotic'. Nevertheless, the performance ends with the Westie persona under no apparent threat of misinterpretation - he is definitely not gay. This result stems in part from dynamic cooperation between the comedian and audience, which similar to many social activities, is more tacit than explicit. Yet this reading of the performance is achieved, and to understand how, we can closely look at the details of the comedic material, the comedian's embodied display and lexical choice. Through this close analysis we see that the performance displays 'communicative artistry', even if the basic joke materials are relatively well worn.
\end{abstract}

\section{INTRODUCTION}

In Philip Roth's (2000) novel The Human Stain, set when Monica Lewinsky's affair with Bill Clinton created international news, there is a darkly humorous dialogue with typically Rothian sexual preoccupations. The novel's protagonist is on the university 'green' and he overhears a conversation between three young male professors, as follows: 
"If Clinton had fucked her in the ass, she might have shut her mouth. Bill Clinton is not the man they say he is. Had he turned her over in the Oval Office and fucked her in the ass, none of this would have happened.... If he can't read Monica Lewinsky, how can he read Saddam Hussein? ... But what he didn't see was that he had to fuck her in the ass. Why? To shut her up.... Had he fucked her in the ass, I doubt she would have talked to Linda Tripp. Because she wouldn't have wanted to talk about that."

"She wanted to talk about the cigar."

"That's different. That's kid stuff. No, he didn't give her regularly something she didn't want to talk about...."

"In the ass is how you create loyalty."

"I don't know if that would have shut her up. I don't know that shutting her up is humanly possible...."

"Still, you have to admit that this girl has revealed more about America than anybody since Dos Passos. She stuck a thermometer up the country's ass. Monica's U.S.A."

(Roth, 2000:146-148, original emphasis)

Below I focus on a standup comedy performance that has a slightly different reference to anal penetration than Roth's in the ass' dialogue. Nevertheless, as a beginning point, Roth's dialogue is useful as it foregrounds some everyday inferences about the body and male/female sexual dynamics. For the men conversing, sexuality (and politics) is a hyper-masculine world where the male sexual role is to penetrate the female. The fact that a male can choose the anus rather than the vagina as the site of penetration just shows that men want all kinds of sex. The corollary of this first point is the common notion that women are reticent to give the full variety of sexual practice, and probably not with the frequency desired by men (Kothoff, 2006; Kulick, 2003). Furthermore, this dynamic of strong desire versus relative passivity can be used as a power play by women. Note though the suggestion by Roth's characters as to how norms about anal sex can reverse this power dynamic: "he had to fuck her in the ass ... to shut her up". The key thing to note here is the assumption that anal sex is a shameful practice: it is so shameful that it is the only thing that would have kept Lewinsky quiet. The dialogue also contains the interesting statement, 'She stuck a thermometer up the country's ass'. That is, as well as being a site of shame, the anus can be a key site for reading off the 'truth' about cultural practices, values, and mores.

Obviously, these points are not to be taken as absolutes, as the moral evaluation of sexual practices is a relative matter, nevertheless, it is not hard to think 
of many other cultural practices that reiterate the tenor of these points. For example, there is the still common practice of giving insult by the 'up yours' middle finger gesture; not to mention the history of sodomy, homosexuality, and the law, and even the oft repeated point that it is very hard to get men to submit to prostate examination. Such things suggest that we should expect material with an anal theme to appear in comedy because as Seizer puts it, a 'framing condition of the genre is that comedic speech will deviate from the norms and standards of other forms of public speech', and further that 'peppering their speech with obscenity is likewise a technique through which comics communicate an "off the record" attitude. This may make us feel, somewhat paradoxically, that the comedian speaks to us "from the heart" (2011:213-214).

Hence, it is no surprise that humour scholars have found that the details of sexuality, including anality, are a rich resource for making humour (Dundes, 1978; Fine, 1976; Johnson, Stirratt \& Bancroft, 2002; Legman, 1968; Lloyd, 2007; Lockyer \& Atwood, 2009; O’Neill, Greenberg \& Fisher, 1992). A good specific example is Medhurst's discussion of the offensiveness of the British comedian Roy 'Chubby' Brown, whose jokes have a high sexual content as well as relying on the old staple of 'dispatches from the front line of marital warfare' (Medhurst, 2007:189). Citing Bakhtin, Medhurst notes the carnivalesque nature of Brown's bodily fascinations:
Brown performs a kind of carnival surgery ... [working up material] into a saga of farting, menstruation and unusually messy oral sex, hauling into the public sphere the sounds, secretions and suctions conventionally hidden away beneath the surface pieties of romantic love.... The classical body is nowhere to be seen in Brown's sexual imaginary, every body he encounters (not least his own) oozes, drips, emits, sags, sprouts and slobbers. (Medhurst, 2007:190, 193)

This comedic reliance on the profane body is present in the standup comedy focused on below, however, there is a point of difference worth noting in regard to Medhurst's discussion of Roy 'Chubby' Brown. It is this: nowhere in his discussion does he present and analyse extended segments of Brown's comedy performances. Instead, he quickly suggests the applicability of various academic concepts for understanding such comedy, in the process making the interesting comment that,

Anyone who approaches popular comedy intent on academic analysis must encounter the risk of being told one is 'reading too much into things', but it seems profoundly implausible to me that Brown 
should attain such heroic significance for his audience simply as a result of his technical skills in joke-telling, brilliant though these are. The intensity of his success in this precise period of English cultural history suggests that he is tapping into complex and troublesome issues of identity, belonging, location, community and home... (Medhurst, 2007:194)

This reflects a common tension in academic analyses of almost any sociocultural phenomenon, that is, the micro-macro debate. Specifically, for Medhurst, the 'micro-level' - the dynamic mechanisms of joke performance - is not where we should look for answers as to why a comedian is successful, rather, we should look to 'macro-level' factors for satisfactory answers. Supposedly, we should understand the current historical context and pay particular attention to the way comedians tap into 'complex and troublesome issues of identity, belonging, location, community and home' (also see Mintz, 1985). Medhurst does seem to realise that such an emphasis on the 'macro-level' risks 'reading too much into things', nevertheless, it is startling how quickly the need to look at 'technical skills' is dispensed with, as if attention to this level could tell us nothing. As Stokoe has commented in her analysis of sitcom humour, 'There are massive, interdisciplinary literatures on humour and laughter, and on the media, but few studies analyse the actual interaction of television sitcoms beyond the jokes that are told within them' (Stokoe, 2008: 292).

Following Stokoe's lead, here I pay particular attention to the technical organisation on show in one stretch of standup comedy. Whereas many aspects can be taken to comprise the 'technical', here I focus on the connection between the characterisation of people and the activities they are portrayed to be engaged in. In order to get across the grounds for my analysis I have to present a substantial amount of transcript of the comedy performance. I begin below with the final portion of the joke, which is the apparent disjuncture between the comedian's persona and the events he narrates.

\section{THE TWIST IN THE TALE?}

Here are the final few seconds of a standup performance from Ewen Gilmour, a New Zealand male 'Westie' comedian: ${ }^{1}$

But we're doing this, we're farting peanuts, and then Vaughan goes, 'Ewen check this out', and instead of just putting the peanut on his butthole, like we'd been doing previously, he pushed it in a little bit [holds up hand, with slightly serious look on face] (laughter) ... so 
it formed a bit of back pressure, you know, and he went prrbb, and it went peeyooww [hand motion shows rapid peanut expellation] (laughter), and I went, 'fuck it, I'm in' right, so we're both farting these peanuts across the room, pushing them in, going peeyow, peeyow, peeyow, peeyow ... and I was pushing in one of the peanuts right ... (laughter) and you know when you get up to the second knuckle [holding up forefinger, pointing to second knuckle, nodding head] ... (laughter) it's got nothing to do with the peanut anymore, does it [stands with hands on hips, small smile on his face] (laughter) ... that's all from me, enjoy your Christmas peanuts this year. I've been Ewen Gilmour, thank you [walks off to applause]

This was the first piece of comedy that I had seen from this performer, and it immediately struck me as very interesting. The persona of the comedian is a Westie, that is someone from the Western suburbs of Auckland, characterised as working class, rough, masculinist and so on (see his official website, http:// ewengilmour.com for more background details). In fact, with the exception of a dress jacket, Gilmour appears to be wearing a de facto Westie-male uniform: jeans, tee shirt, long hair and goatee beard (see images in figures below). As can be seen in the transcript, he also uses street language, i.e. obscenities. Because of these factors, I was surprised at the final joke as it employs material with a distinctly homoerotic interpretation: there are two men naked from the waist down, sharing the same couch, putting peanuts in their anuses. Of course, as a joke it does not have to be taken as a 'true' story, nevertheless it is told from the position of a consistent 'performance' or 'stage' persona (see Seizer, 2011), and my initial surprise is because Gilmour's persona is strongly heterosexual. If the sociological literature on gender is to be believed, this homoerotic element therefore constitutes a small conundrum. For example, in a useful article on 'talk in a play frame' Coates confidently states that '... the pressures of hegemonic masculinity mean that male speakers must at all times avoid being perceived as gay' (2007:41). Perhaps, by this Coates means unless they are gay, but there is no trace whatsoever in Ewen Gilmour's comic persona that suggests he is. So, my interest in the performance stemmed from this apparent disjuncture. It is best now to consider a fuller transcript of the performance, then base the analytical discussion on this transcript. ${ }^{2}$

\section{GILMOUR'S PERFORMANCE}

It is a short 8.5 minute performance, so Gilmour is straight into his routine. After a 'Good evening ladies and gentleman', he moves directly into a standard of comic material, 'look I've just been finding differences in my marriage.' This 
is given substance by the example of different reactions of his wife and himself to finding a 'booger' hanging out their noses. This is an initial connection to street-level bodily reality, which develops as the performance progresses, and is thoroughly consistent with the Westie persona. We can usefully pick up a full transcription about 2 minutes into his performance, and also consult the first image below to see how Gilmour presents himself. ${ }^{3}$

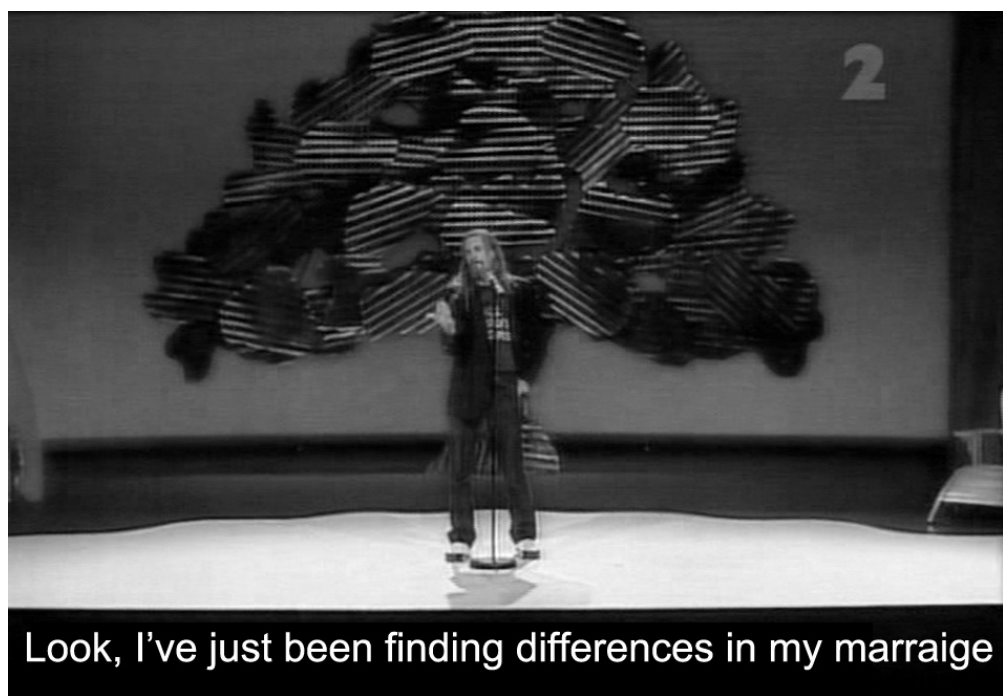

Figure 1

1 You see I've been doing this Christmas comedy gala for 14 years now. And um,

2 yeh, that is a joke, don't worry about it. And I've been making people laugh, but not

3 very often do people come up to me and say, 'Ewen, what makes you laugh?' 'What

4 do you think's funny Ewen?' Well I'll tell you what I think's funny.

5 I think farts are funny (laughter). I think farts are hilarious. Well, men's farts,

6 men's farts are hilarious, ah, women's farts are a bit like a little secret society really,

7 aren't they (laughter). Like a guy just proudly farts, he just goes brrh, brrh, hey that

8 was me (laughter). Whereas a woman will spend all day sneaking out little bits of

9 the same fart (laughter) ... trying not to get caught (laughter). And if they do get

10 caught they'll say something like, 'oh, it must have fallen out' (laughter) [shakes

11 his head] 'I didn't know it was there', it just fell out, man, I mean I understand the

12 concept of farts falling out, but ya still know that they're there, like, you're with a

13 bunch of mates and you see a set of stairs and you know you've got a fart that is

14 going to fall out. You say to your mates watch this, brh, brh, brh, brrrh, brrh

15 [tunefully, with motions of climbing stairs, with victory raise of arms] (laughter). 
16 And you're an instant farting legend amongst your mates. Of course, you're not 17 allowed back into the Warehouse (laughter) ... Because guys have fun with their 18 farts. I've got a friend of mine, Vaughan King, he's quite a farter, I'm quite a 19 farter, we're just naturally good farters, okay (laughter). And ah, we've been trying to speak to each other using farts (laughter) okay, just the other day he came up to me and he went (raises leg) harrow (laughter) and I was pretty impressed, you know, so I tried to respond in kind by going (raises leg, farty voice), 'how are you', but I ended up writing half of it down (laughter) ... But that's the kind of fun guys have with farts, compared with a woman's secret society. And here's an example. My wife and I went shopping for a duvet in K Mart, because we're not allowed back in the Warehouse (laughter), and we're shopping for a duvet, which I've found out is just a really flash word for bedspread, it's so they can charge more, okay, and we're standing there and I'm going 19.95, what a bargain, but my wife goes, 'yeh, but for 29.95 we could get one with a floral pattern'. So, I start arguing with her, I'm going, look it's night-time, the lights are off (laughter), my eyes are closed, I'm asleep, you know, and so I don't care what sort of pattern it's got on it, it could have naked pictures of my mother in-law on it for all I care (laughter). And when I say I'm arguing with my wife, it's all just happening up here, right [tapping the side of his head] (laughter and clapping). I never say it out loud, you know, I'm not stupid, right (laughter). And I sort of turn to her and like, ' $m m m$ ', and ah she'd gone, she'd walked to the end of the aisle, and she's looking at the end of the aisle, and I'm thinking, maybe she's found a duvet, with a floral pattern, for 9.95, but to save money they've called it a bedspread, so I start walking towards the end of the aisle where my wife is standing, but before I get to her she sees me coming and just looks at me and looks back, and off and around the corner and gone. But I know I need to stop where she was to look at what she was looking at in case I get questioned when I get home, okay (laughter). And so I walked to where she was standing and I walked into what [slowly] I can only describe .... as an envelope of warmth, ladies and gentleman (laughter) it was something really big that had fallen out of her arse (laughter), and I mean really big, I mean really big, okay, and it broke open, and when it broke open it broke open baadd, it was [grimacing facial expressions] you've heard of Agent Orange, this was Agent Brown, just augh, augghh, and just as I'm getting my face back to normal, a family of 4 walk around the corner (laughter) ... into the envelope of warmth (laughter), and the kids go, 'oh, Jesus Dad', and he goes, 'it wasn't me, it was this filthy bastard here' (laughter) pointing at me, [raising hands] and I'm like, 'this is not my envelope of warmth, man' (laughter) it's somebody else's mail (laughter)... But guys have fun with their farts, like I told you, Vaughan and I we're just very very good farters, okay, and during the Rugby World Cup, he was over at my place one night, and we were farting up a storm, just having fun with them, you know, we started lighting our farts, coz that's pretty funny, right 
57

58 63 sudden Vaughan goes, 'Ewen, check this out', and so I turn around and Vaughan 64 has taken off his pants and his underpants, okay (laughter), now he's assumed a 65 position to light a fart but instead of lighting the fart he got a peanut, and he put the 66 peanut on his butthole and he went, prrrbb, and the peanut went like that 67 [indicating a parabola in the air] (laughter). And I just went, 'fuck it' [shakes his 68 head] ... 'I'm in' [miming taking off his pants] (laughter), okay, so I took my pants 69 and underpants off as well, and we're both on the couch there, and we're farting 70 these peanuts off the couch, and it's like tiddlywinks for grown-ups. We even got 71 a cup and put it down on the floor there, so they're going like that, you know 72 [mimes multiple parabolic motions], and we're both farting them off the couch 73 into the cup, and if someone gets one into the cup, the other person has got to eat 74 all the other peanuts (laughter), it's brilliant, brilliant ... [laughs himself] ... I know 75 you're gonna try that at home ... and ah, but just wait til you're alone, alright 76 (laughter). But we're doing this, we're farting peanuts, and then Vaughan goes, 77 'Ewen check this out', and instead of just putting the peanut on his butthole, like

84 know when you get up to the second knuckle [holding up forefinger, pointing to 85 second knuckle, nodding head] ... (laughter) it's got nothing to do with the peanut 86 anymore, does it [stands with hands on hips, small smile on his face] 87 (laughter) ... that's all from me, enjoy your Christmas peanuts this year. I've 88 been Ewen Gilmour, thank you [walks off to applause].

\section{ANALYSIS}

In lines 1 to 5 there is the initiation of the core topic for the performance: farts. But, connecting to the earlier introduction of 'differences in my marriage' there is an important subset to this topic, the fact that men and women occupy different worlds when it comes to farts and farting. 'Men's farts ... are hilarious; women's farts are a bit like a little secret society, really, aren't they?' Note, that the 'differences in my marriage' opener has established that the comedian is 
married, that is, by inference heterosexual. Then there follow some lines which give humorous detail of these differences: 'a guy just proudly farts ... whereas a woman will spend all day sneaking out little bits of the same fart'. So, a fairly stereotypical distinction is being utilised that women tend to be more concerned with politeness, but men are happy to be coarser, this being consistent with what you would expect from a 'Westie' man.

Then in line 12, having primarily used the categories 'man'/'woman', a more specific 'membership collection" is introduced: 'you're with a bunch of mates', the language of 'mates' again reinforcing the Westie persona. This time the details are given of how by tunefully farting whilst ascending stairs, you can become an 'instant farting legend amongst your mates'. Then in line 18 we see the interesting naming - Vaughan King - of 'a friend of mine', with his chief activity-characteristic being that 'he's quite a farter'. We then get details of how the two 'mates' have been 'trying to speak to each other using farts'. Again this is thoroughly consistent with the typifications that the Westie persona puts in place, that is, men are not natural communicators, and are amused by simple things - even grown men revert to the schoolboy behaviour of talking via farts. This line of joking then leads to the scatology of Ewen having crapped his pants trying to speak via farts.

The end of the speaking by farting joke is then the place for a return to the 'wife and I' comparison in line 24, which interestingly also repeats the 'woman's secret society' phrase introduced earlier. Gilmour tells of shopping with his wife for a duvet, the Westie persona being reinforced by a standard kind of working class complaint about fancy language: a duvet is just a fancy name for a bedspread (line 27). Then the persona is reinforced through the patter about 'arguing with the wife', where a standard complaining reference to the motherin-law is made. But note the important secondary joke in this patter: 'when I say I'm arguing with my wife, it's all just happening up here, right [tapping the side of his head]' (line 33). This is all rather interesting given the prior joke that men might prefer talking via farts; now, we see added to the characteristics of Westie man is that he is dominated by 'the wife', at least on domestic matters. A picture is built up of the dutiful Westie husband lagging behind the wife while shopping, paying attention so he can answer questions when they get home. This allows the introduction of the scenario where he must walk into the space she has vacated, where she has unfortunately left an 'envelope of warmth'. This joke is filled out by Ewen then being held responsible for the horrible smell of his wife's fart, this being nicely consistent with the theme of male/female differences over farting: the former open, the latter like a secret society, filled with concerns about politeness. Note too that it is the male who is falsely accused of 
being a horrible farter due to the operation of the contrasting women's 'secret society. These points about male/female differences are subtly interwoven in the joke-telling, but form an important context as the performance progresses towards its culmination.

In line 51 there is a new sub-joke set up with, 'But guys have fun with their farts, like I told you, Vaughan and I we're just very good farters. The setup then is that during the Rugby World Cup - watching rugby being traditional masculine activity - Vaughan and Ewen were 'farting up a storm', lighting farts and so on. Then a significant development in the joking is signalled with 'and then all of sudden Vaughan goes, 'Ewen, check this out'. In standard this-then-that narrative accounting, Gilmour details turning around to see that 'Vaughan has taken off his pants and underpants' and has devised a new farting activity involving fart-powered peanut expulsion. There is a simple bit of comedic timing employed here, the details of which are supplemented by consideration of visual images of the comedian. ${ }^{5}$ In response to Vaughan's development, Gilmour says 'And I just went, 'fuck it' [shakes his head]' (see figure 2) and then pauses.

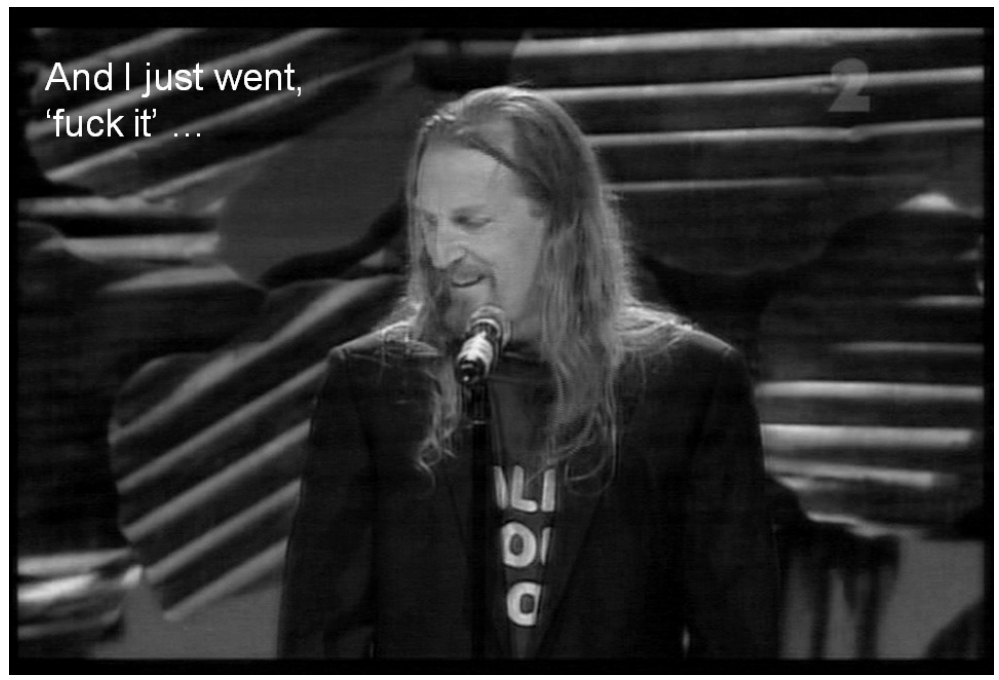

Figure 2

But instead of following the 'fuck it', said looking down and with a slightly disgusted look on his face, with what might normally follow, that is, something like 'that's sick, weird, etc', he says 'I'm in!' (see figure 3) and then mimes taking off his pants. 


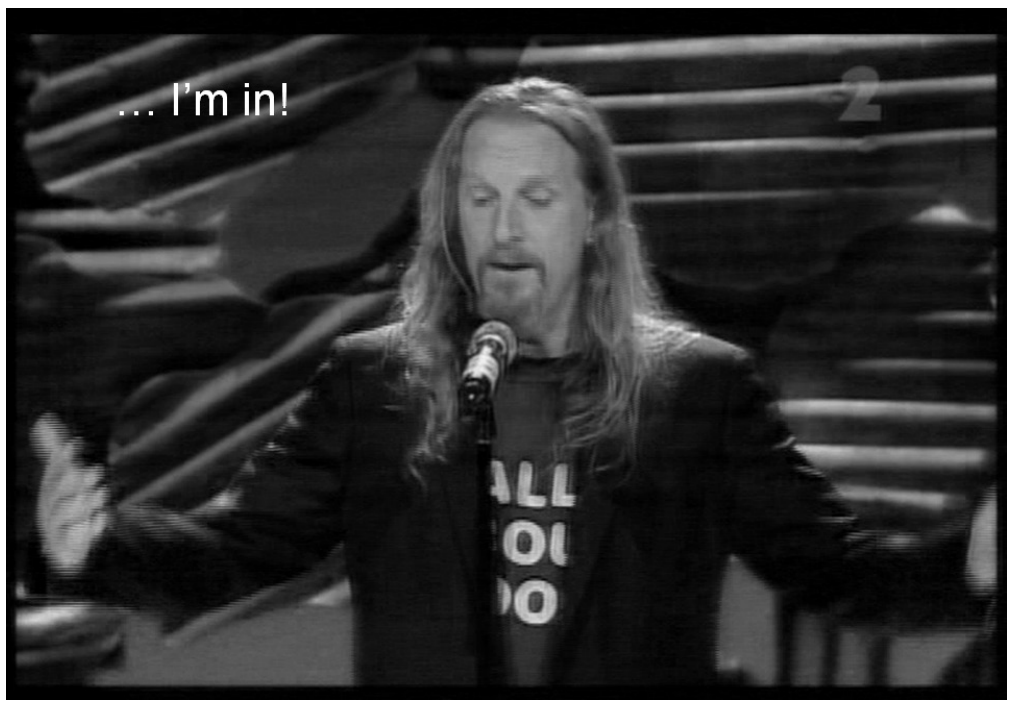

Figure 3

In the spirit of mateship and competition Ewen joins in: 'okay, so I took my pants and underpants off as well, and we're both on the couch there' (lines 68-69). This deserves a pause for thought. There is no break to the flow of narrative, no hedging, just a simple declaration that the two grown men minus pants and underpants are on the same couch 'farting these peanuts off'. If we were to bracket the humorous framing and build up a serious visual picture of the practical management of such activity it would be rather interesting: to fart a peanut up from one's anus you would need to be prostrate on your back, legs open, with the anus presented upwards. Of course, this means that the men's penises are also somewhere in the picture, as they are naked from the waist down. But note how the penis goes unmentioned in the joke narrative. ${ }^{6}$ The actual bodily mechanisms, including where the penis is, are not highlighted as the emphasis of all the previous narrative is that men have fun with their farts, and that mateship involves open competition over all kinds of things. Competition is a key word, as it takes any reading of the men's exposed genitalia away from what can also result from that state - sexual intimacy - emphasising that they are only naked for competitive, fun purposes. This of course is acceptable male behaviour and not to be taken as homoerotic. This competitive focus is immediately emphasised in the next narrative development: 'we even got a cup and put it down on the floor there ... and if someone gets one into the cup, the other person has to eat all the other peanuts' (70-74). This is nothing less than a connection between anal sexual practices and food, and it is described 
as 'brilliant, brilliant', so much so that you will want to try it at home, 'but just wait til you're alone, alright'. This fits well with the comment that 'it's like tiddlywinks for grown-ups'.

The important final joke of the performance then starts at line 76 with, 'But we're doing this', and then Gilmour goes on to describe Vaughan pushing a peanut 'in a little bit'. Simultaneous to saying this he raises his hand, and has a serious look on his face (see figure 4), effectively indicating that the audience should hold the 'normal' negative judgement about such a practice.

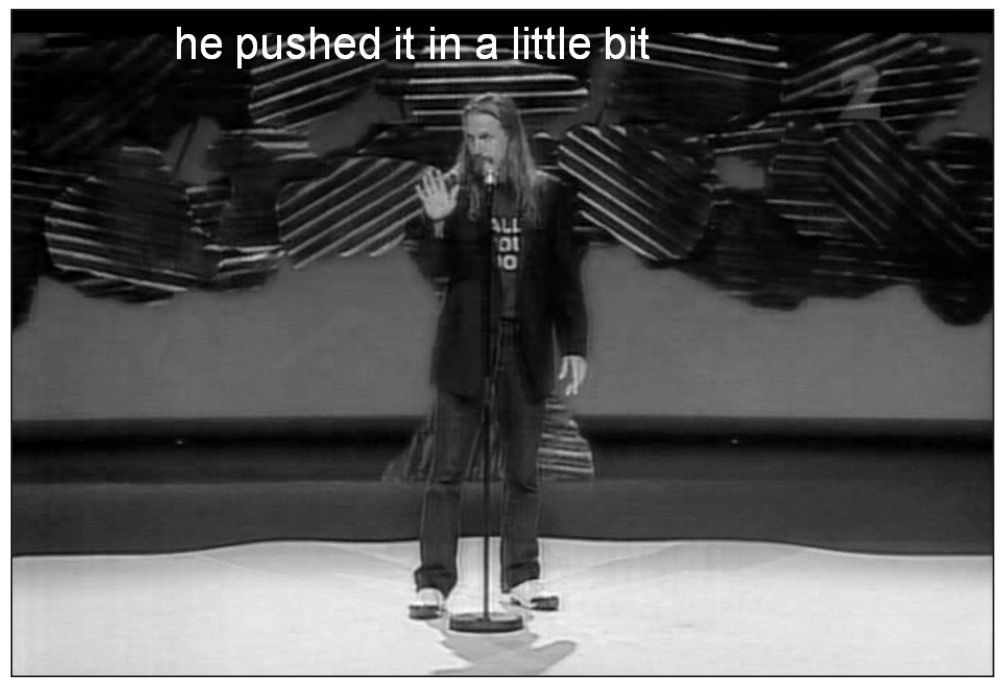

Figure 4

Then there is the immediate payoff to the joke, a lot of which is realised by the sounds prrb, peeyoow, indicating the fart and the trajectory of the expelled peanut. Importantly, the final lines begin with the phrase 'and you know', the you being the generalised you of the audience to the joke; this then allows the final delivery, dependent on what the audience knows, but which will remain unsaid. That is, 'when you get up to the second knuckle ... it's got nothing to do with the peanut anymore, does it?' (see figure 5) In other words, the joke is a reference to the possible pleasures of anal penetration.

Thus the structure and delivery of the performance has something of a 'twist in the tale' (excuse the pun) nature to it. It is not an obvious punch line that finishes the performance, rather the audience is left with a reference to a sexual 


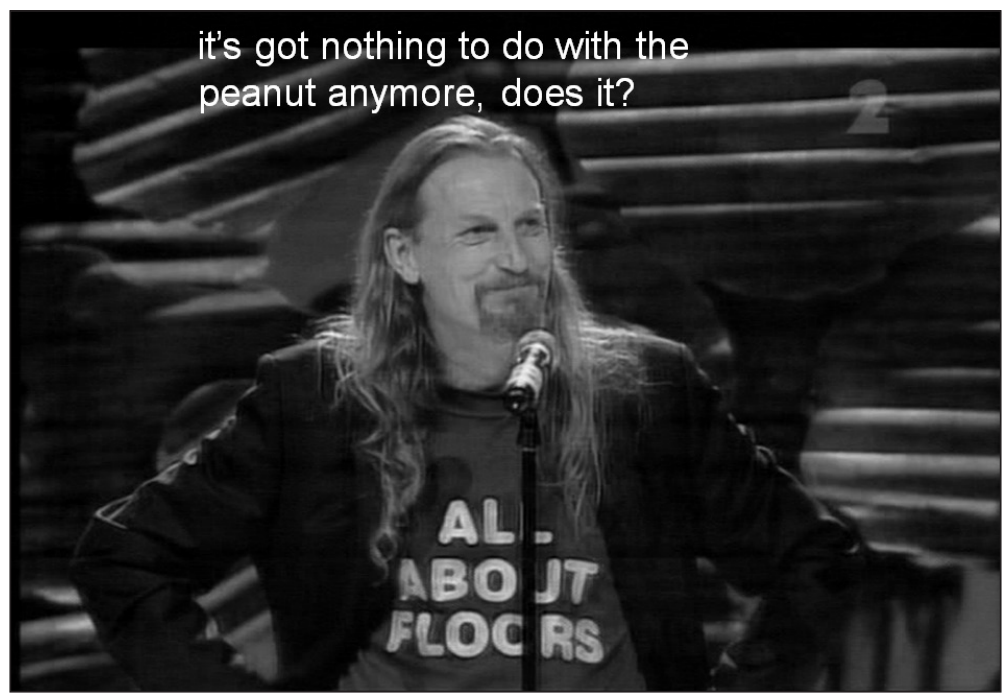

Figure 5

practice which is not named, and not on the face of it, humorous in itself. The non-obvious ending invites multiple searchings of the prior content for what it 'really' means, that is, the humour depends on a kind of 'understanding test'. The activity engaged in first has to do with expelling peanuts by farting, but when you have your finger pushing a peanut up your anus (as a man), and you get to the second knuckle, it has 'nothing to do with the peanut anymore, does it?', all said with a wry grin on the comedian's face. Literally, a question is asked of the audience - 'does it?' - and the humour lies in asking such a question - do you know about the pleasures of anal penetration - without referring to the broader topic in any explicit way. Any resulting laughter or grinning is partly of an, 'I get it, I know what you are referring to' kind.

The humour lies in being able to talk about something 'naughty', or even 'shameful', without being explicit, by using understood references (the same process at work in double entendre - see Lloyd, 2007). There is also some cheek in the final, 'enjoy your Christmas peanuts this year'. It is almost as if the comedian has said, 'I may adopt the persona of a unsophisticated Westie, but I've just tricked you - I've made you think and laugh about 'shameful' practices that in polite company you probably wouldn't admit to knowing about'. Further, the audience may, in reflecting on the final lines, make interesting connections to the prior themes and content of the performance. For example, the prior material about women's farts being like a 'secret society', and the general 
antagonistic differences between husbands and wives, are now material that a searching audience can utilise for a kind of reflective appreciation of the joketelling. In playing with their anuses on the couch, perhaps it is Vaughan and Ewen who have the real 'secret society', and just like the 'arguing with the wife in his head' joke, the activities they get up to are never going to be verbalised to 'the wife.' It does not matter that all this is a joke-story, that is made up, as the everyday-practice inferences are there waiting to be found in the material.

\section{CONCLUDING DISCUSSION}

The British comedian Ken Dodd famously said, 'the trouble with Freud is that he never played the Glasgow Empire Saturday night' (Dodd, n.d.). Presumably Dodd was aware of Freud's (1905) famous work on jokes, with his point being that there is a world of difference between theorising humour and the practicalities of standing up in front of a live audience and making them laugh. Of course, the latter task was never Freud's concern, however other social scientists have been more aware of the possible connections between the two activities. For example, in his neglected essay 'fun in games' (1961), Goffman subtly notes the central tension of humour: 'As every psychotic and comic ought to know, any accurately improper move can poke through the thin sleeve of immediate reality' (1961:72, emphasis added). An inaccurate improper move will produce humour about which too many people take offence or which will not be understood, whereas excessive propriety or politeness in attempted humour will produce a muted reaction with little or no laughter. This is why stand-up comedians take weeks to write and prepare a successful hour long routine (Crohn, 2011). It takes a great deal of careful work to get the balance right, and audiences are quick to let the comedian know when they have failed, either by not-laughing, audible groans, or outright heckling.

In my view, Gilmour's performance does get the balance right, hence this is why the term 'communicative artistry' is applicable to his standup comedy performance. I take the term from Seizer (2011) who uses it once only, nevertheless, the details of her ethnographic work on stand-up comedy make clear what she means:

A successful comedian gains the audience's confidence by quickly demonstrating that he or she can handle the spotlight and deliver the funny, in a register and style that is both accessible and convincing to a roomful of strangers whose tastes and predilections may vary widely. That is, a comedy club crowd expects to be verbally tick- 
led by original material, and sufficiently surprised, delighted even, into laughing at the comic's act. (2011:211)

Furthermore, the self-respecting road comic also has an eye to gaining respect from their peers - other comedians - and will avoid, as much as possible, telling 'hack jokes'.

The perhaps neglected work of Sacks (1978) on 'technical considerations of a dirty joke' also adds weight to my argument that Gilmour's performance displays communicative artistry. Sacks makes the point that dirty jokes are 'elaborately organized' and can be approached as serious sources of information, consistent with my suggestion that the Gilmour joke works as an 'understanding test'. Sacks also notes that the artfulness of a joke sometimes lies in 'concealing some of the ways the joke works on its recipients from those recipients' (1978:250), and this too seems to be at work in the performance. However, there is one interesting point of departure. Sacks comments about the joke he analyses that:

Furthermore, that information which you might put into a dirty joke format has a sort of safety to it, in that teller is not a character. So, insofar as the joke contains possibly embarrassing or denigrating information, it isn't information to be affiliated to teller, and recipient need not affiliate to it. (1978:262)

Obviously, in the case above Ewen Gilmour is telling the joke as participant, reiterating my interest in the joke: how does he tell this joke, as a Westie, without risking a wealth of potential for embarrassing or denigrating information to be applied to him as teller/participant?

It is important here to consider the detail. When Gilmour gets to the key parts of the final joke, there is an interesting shift from the 'I' to 'You': 'and I was pushing in one of the peanuts, right ... and you know when you get up to the second knuckle' (84-85). He does not say, 'when I got up to the second knuckle, that is, the first person narrative previously operating in the performance. This change to the second person 'you know when you' is what subtly sets up the understanding test, and it seems to me also constitutes a partial bracketing of the Westie persona. That is, Gilmour finishes the performance almost out of persona - note the wry grin shown in Figure 5-almost inviting the audience to look for more general categorisations in order to understand what they have just heard. In my view, the jokes are not to be read as serious information about 
the sexual practices of Westie men. Of course, 'Westie man' as a construction, a fabrication, may have different contours, but here it is one about which we all somehow know that anal sexual practice is not a standard activity of such a person. Whereas, engaging in competition with mates, being cheeky about sex, and talking sex in a profane manner, is persona-consistent. The bulk of Gilmour's performance, including all the important bodily gestures, clearly confirms this.

It is to the jokes in the bulk of the performance that the audience is primed to look for their answer as to why the performance ended on such an open note, finding there exactly the old staple of 'dispatches from the front line of marital warfare' (Medhurst, 2007:189), or as introduced by Gilmour, 'differences in my marriage. We see ample husband/wife (or man/woman) comparisons, the notion of women having a 'secret society' reaction to things impolite, and contrasts between what happens when a man is with a woman and when he is with his 'mates' having fun. These themes are the immediate context within which the 'twist in the tale' ending is positioned, and thus they form the first resource that the audience has recourse to in understanding the final joke. It is almost as if the comedian is artfully toying with the audience: he has a persona which tends to rely on relatively simple masculinity - the bulk of the jokes - but then is able to subtly switch from that persona by dropping hints of 'secret practices' inconsistent with simple heterosexual masculinity.

To conclude I would like to connect to Roth's 'shutting Lewinsky up' dialogue to try to make a broader point from what has been a very specific analysis. There is a sensible sociological question that can be asked in relation to the above material: is a cultural preoccupation with a type of sexual practice that is taken to be more shameful driving this humour? As Mary Douglas said some time ago, 'all jokes are expressive of the social situations in which they occur' (1968:366). Once something is made shameful or taboo there is only more attention drawn to it, and of course humour plays with boundaries and edginess, hence it is no surprise that anal sexual practices can be used to make humour. In contrast, my view is that in itself anal sexuality is not overly significant in the humour; it is not a central cultural preoccupation, rather it is a useful resource that can be used to make humour in relation to other cultural issues and tensions. The Roth dialogue is mostly about how unchecked male desire gets men into trouble, not insignificantly through the actions of the objects of their desire, that is, women. 'Fucking in the ass' is not a central cultural preoccupation, rather it is a resource to make the point that 'nothing would have shut Lewinsky up', in other words, women will always be of trouble to men once they have entered into sexual relations with them. 
Interestingly, the Westie standup performance has a similar theme at its heart the differences between husbands and wives, men and women. On the surface, the comparison is that men like to have fun with farts, whereas for women farts are like a secret society. However, the twist in the tale of the performance leaves the audience with a search for meaning - given the fairly standard nature of the fart jokes of most of the performance, the meaning of the finger up the anus ending is not immediately apparent. And it is reinforced with the final utterance, 'Enjoy your Christmas peanuts', which is full of tricksterish interpretive possibilities. Do we all have secrets when sexuality is at stake, and how do male/female differences play out in that realm? Anal sexual practices are not the essential core of Gilmour's performance, rather, because of its edginess it is a convenient resource to broach that old chestnut of humour - male/female differences, particularly regarding sex.

In arguing this I am doing something consistent with what Medhurst (2007) suggested, that is looking for broader cultural preoccupations. But there is an important difference: I have tried to do this by attention to the detail of the comedic performance - sequencing, categories of people and their associated activities - and not by some semi-magical identification of the relevant broader cultural preoccupations. The problem with many academic approaches is that the 'social situations' in which jokes occur are almost endlessly specifiable, so we have no convincing means of telling an actually operating 'social situation' from ones that are merely plausible, or in fact implausible. But, as I have suggested, it would be a mistake to argue that either the Roth dialogue or the Gilmour performance, reflect a current cultural preoccupation with anal sexual practices. Rather, they are evoking something more generic, and at least with regard to Gilmour's performance we don't need to specify that reductively, for it is made pretty apparent for us - the comedian opens with 'I've just been finding differences in my marriage. That is, the broader theme is named in the beginning and is reiterated throughout the details of the comedic performance. It is the subtlety of this interweaving, delivered from a far from subtle comedic persona, which qualifies the performance as communicative artistry, despite the fact that fairly traditional fart jokes comprise the basic material.

\section{ACKNOWLEDGEMENTS}

An earlier version of this article was presented at the International Society for Humor Studies annual conference in Boston University, July, 2011. Thanks to Susan Seizer and Moira Smith who attended my presentation and made useful comments. Also thanks to the two anonymous reviewers. 
NOTES

1 Taken from The Comedy Christmas Gala for 2008 screened on TV2 on December 17. This was the very first TV2 comedy gala, featuring 11 comedians performing live in front of an audience, interspersed with MC comments from Te Radar. Ewen Gilmour's performance is second from the end and lasts for 8.5 minutes (with no ad breaks). As standup comedy this makes the performance somewhat unusual because as Seizer (2011:21) notes the majority of venues for standup comedians are bars, meaning patrons will be drinking, hence comedians can expect looser than usual social behaviour. Viewing the full Christmas Gala leads me to the very rough observation that the audience also looks more 'middle class' than you might expect in the usual bar doubling as comedy venue.

2 Transcription is by the author from the recorded television show. There is no attempt to transcribe minute details of the delivery, but I have inserted in hard brackets comments about the bodily gesture of the comedian, where these seemed important, and in soft brackets (laughter) where significant laughter occurred.

3 Figures 1 to 5 are screensnaps from the television show.

4 'Membership collection' is a technical term taken from a type of analysis founded by Harvey Sacks called Membership Categorisation Analysis (MCA). In this article I am eschewing using the technical vocabulary of MCA as it seems unnecessary for the level of analysis I wish to make. However, for those interested in the details of MCA and how it can be applied to humorous data, see Lloyd (2011).

5 Gilmour's bodily gestures are a very important part of the performance. Hand motions, control of facial grinning, and timing of his own laughter, are all tightly controlled. Space constraints limit the amount of visual material that can be shown, nevertheless in the few images reproduced here readers should be able to see how the regulation of bodily gesture contributes to the overall communicative artistry. See Clayton (2007) for an interesting and relevant discussion of the body in Hollywood slapstick comedy.

6 I owe this observation to an anonymous reviewer. As to whether the lexical similarity between 'peanut' and 'penis' is significant, I am unsure. But perhaps this possibility just adds to the mystery of the joke for any hearer who wishes to unpack it. We should not assume that it is only academic commentators engaging in such unpacking, for this is precisely what the final joke invites the audience to do. 
Article $\cdot$ Lloyd

\section{REFERENCES}

Clayton, A. 2007 The Body in Hollywood Slaptstick. Jefferson: McFarland.

Coates, J. 2007 'Talk in a play frame: more on laughter and intimacy', Journal of Pragmatics, 39 (1):28-49.

Crohn, D. 2011 Personal communication, July 7, 2011.

Dodd, K. (n.d.) 'The trouble with Freud is that he never', Columbia World of Quotations. Retrieved October 17, 2011. From Dictionary.com website: http:// quotes.dictionary.com/The_trouble_with_Freud_is_that_he_never

Douglas, M. 1968 'The social control of cognition: some factors in joke perception', Man, 3:361-376.

Dundes, A. 1978 Into the endzone for a touchdown: a psychoanalytic consideration of American football, Western Folklore, 37 (2):75-88.

Fine, G.A. 1976 'Obscene joking across cultures', Journal of Communication, 26(3):134-140.

Freud, S. 1905 Jokes and Their Relation to the Unconscious. Penguin Freud Library, vol. 6. Harmondsworth: Penguin.

Goffman, E. 1961 'Fun in games', in E. Goffman Encounters. Harmondsworth: Penguin: $17-72$.

Johnson, C., Stirratt, B. and Bancroft, J. (eds) 2002 Sex and Humor: Selections From the Kinsey Institute. Bloomington: Indiana University Press.

Kothoff, H. 2006 'Gender and humour: the state of the art', Journal of Pragmatics, 38:4-25.

Kulick, D. 2003 'No', Language and Communication, 23:139-151.

Legman, G. 1968 Rationale of the Dirty Joke. New York: Grove Press.

Lloyd, M. 2007 'Rear gunners and troubled privates: wordplay in a dick joke competition', Journal of Sociolinguistics, 11(1):5-23. 
Lloyd, M. 2011 'Miss Grimshaw and the white elephant: categorisation in a risque humour competition', Humor, 24(1): 63-86.

Lockyer, S. and Attwood, F. 2009 “"The sickest television show ever”: Paedogeddon and the British Press', Popular Communication, 7(1):49-6o

Medhurst, A. 2007 A National Joke: Popular Comedy and English Cultural Identities, London: Routledge.

Mintz, L.E. 1985 'Standup comedy as social and cultural mediation', American Quarterly, 37 (1):71-80.

O’Neill, R.M., Greenberg, R.P. and Fisher, S. 1992 'Humor and anality’ Humor, 5(3):283-291.

Roth, P. 2000 The Human Stain. New York: Houghton Mifflin.

Sacks, H. 1978 'Some technical considerations of a dirty joke', in J. Schenkein (ed) Studies in the Organization of Conversational Interaction. New York/San Francisco/London: Academic Press:249-275.

Seizer, S. 2011 'On the uses of obscenity in live stand-up comedy', Anthropological Quarterly, 84(1):209-234.

Stokoe, E. 2008 'Dispreferred actions and other interactional breaches as devices for occasioning audience laughter in television "sitcoms", Social Semiotics, 18(3): 289-307. 